\title{
Implikasi Yuridis Kebijakan Formulasi Alat Bukti Elektronik
}

\author{
Eko Surya Prasetyo \\ University of Jember, Indonesia \\ ekosuryaprasetyo@gmail.com
}

\author{
Y. A. Triana Ohoiwutun \\ University of Jember, Indonesia \\ anaohoiwutun@ymail.com
}

\author{
Halif \\ University of Jember, Indonesia \\ haliffadhil@yahoo.com
}

\begin{abstract}
Formulation policy occupies a strategic role in the efforts to eradicate criminal acts, as law enforcers are bounded by prevailing laws and regulations. The issue of article formulation is only the surface of the problem when using electronic evidence in practice. The Law Number 31, Year 1999, on Corruption Criminal Act acknowledges electronic evidence as an extension of "petunjuk", while in The Law Number 8 Year 2010, the Money Laundering Criminal Act, electronic evidence is recognized as an independent instrument of evidence. This article examines the underlying reasons for differences in formulation policy, in terms of the legislator's rationales. This article will also expose juridical implications for the recognition of electronic evidence in both acts. The article uses normative yudiris-legal research that analyses law through a building norm system. Based on legislative review, by tracking the legislation rationale, it is found that there is no fundamental reason for the classification, but it is only a legal policy because of legislation Based on the conceptual study, it is understood that electronic evidence, "petunjuk", is weaker than independent evidence. This article concludes with the suggestion to include electronic evidence in the Criminal Procedure Code (KUHAP), with a 'stand-alone' position that is not part of other evidence.
\end{abstract}

KEYWORDS: Formulation Policy, Electronic Evidence.

Copyright $\odot 2018$ by Author(s)

This work is licensed under a Creative Commons Attribution-ShareAlike 4.0 International License. All writings published in this journal are personal views of the authors and do not represent the views of this journal and the author's affiliated institutions.

HOW TO CITE:

Prasetyo, Eko Suryo, Y.A. Triana Ohoiwutun \& Halif. "Implikasi Yuridis Kebijakan Formulasi Alat Bukti Elektronik" (2018) 5:2 Lentera Hukum 189-208.

Submitted: April 18, 2018 Revised: April 29, 2018 Accepted: June 06, 2018 


\section{PENDAHULUAN}

Perkembangan teknologi informasi dan komunikasi memiliki dua sisi yang saling bertolak belakang. Pada satu sisi, memberikan kontribusi bagi peningkatan peradaban manusia. Pada sisi lain, hal ini berpotensi mendorong perkembangan kejahatan, bahkan memunculkan jenis kejahatan baru. Kejahatan di bidang teknologi dan informasi memiliki karakteristik tersendiri diantaranya dilakukan oleh orang yang memiliki keahlian khusus (white collar crime) serta sering kali dilakukan secara melintasi batas negara (transnational crime). ${ }^{1}$ Dalam pembuktian kejahatannya memiliki tingkat kesulitan tersendiri sehingga tidak dapat didekati dengan ukuran dan kualifikasi hukum konvensional sebab jika cara ini yang ditempuh akan terlalu banyak hal yang lolos dari upaya pengungkapannya. ${ }^{2}$ Dengan demikian, diperlukan adanya perlakuan khusus dalam proses pembuktian kejahatannya salah satunya dengan menjadikan alat bukti elektronik sebagai alat bukti yang sah. Secara legalitas eksistensi alat bukti elektronik dalam pembuktian tindak pidana pertama kali diakui dalam UndangUndang Nomor 20 Tahun 2001 tentang Perubahan atas Undang-Undang Nomor 31 Tahun 1999 tentang Pemberantasan Tindak Pidana Korupsi (UU Tipikor). Eksistensi alat bukti elektronik juga dirumuskan dalam Undang-Undang Nomor 15 Tahun 2002 tentang Pencegahan dan Pemberantasan Tindak Pidana Pencucian Uang (UU PPTPPU) yang kemudian tetap dipertahankan dalam Undang-Undang Nomor 8 Tahun 2010 tentang Pencegahan dan Pemberantasan Tindak Pidana Pencucian Uang (selanjutnya disebut UU Pencegahan dan Pemberantasan Tindak Pidana Pencucian Uang/PPTPPU).

Walaupun kedua undang-undang tersebut mengatur eksistensi alat bukti elektronik yang sama namun memiliki bentuk formulasi yang berbeda. Eksistensi alat bukti elektronik dalam Pasal 26A UU Tipikor menentukan bahwa alat bukti elektronik yang berupa informasi yang diucapkan, dikirim, diterima, atau disimpan secara elektronik dengan alat optik atau yang serupa dengan itu; dan dokumen, yakni setiap rekaman data atau informasi yang dapat dilihat, dibaca, dan atau didengar yang dapat dikeluarkan dengan atau tanpa bantuan suatu sarana, baik yang tertuang di atas kertas, benda fisik apapun selain kertas, maupun yang terekam secara elektronik, yang berupa tulisan, suara, gambar, peta, rancangan, foto, huruf, tanda, angka, atau perforasi yang memiliki makna, khusus dalam pembuktian tindak pidana korupsi merupakan alat bukti yang sah sebagai sumber perolehan alat bukti dalam bentuk petunjuk sebagaimana dimaksud dalam Pasal 188 ayat (2) Kitab Undang-Undang Hukum Acara Pidana (KUHAP) artinya alat bukti elektronik hanya sebagai bagian dari alat bukti yang diakui KUHAP. Sedangkan dalam Pasal 73 UU PPTPPU terdapat dua alat bukti yang sah yaitu alat bukti sebagaimana dimaksud dalam Hukum Acara Pidana; dan/atau alat bukti lain berupa informasi yang diucapkan, dikirimkan, diterima, atau disimpan secara elektronik dengan alat optik atau alat yang serupa optik dan dokumen. Kedua

Budi Suhariyanto, Tindak Pidana Teknologi Informasi (Cybercrime) Urgensi Pengaturan dan Celah Hukumnya (Depok: Raja Grafindo Persada, 2012), hlm. 12.

2 Maskun, Kejahatan Siber (Cyber Crime) Suatu Pengantar (Jakarta: Kencana, 2013), hlm. 32. 
alat bukti yang dipisahkan oleh kata hubung "dan/atau" mengindikasikan bahwa kedua alat bukti tersebut berdiri sendiri dan alat bukti yang satu bukan bagian dari alat bukti yang lain, maka alat bukti elektronik dalam UU PPTPPU merupakan alat bukti yang berdiri sendiri. Dengan demikian, dalam kedua undang-undang tersebut terdapat bentuk formulasi alat bukti elektronik yang berbeda yakni sebagai perluasan alat bukti petunjuk dan sebagai alat bukti yang berdiri sendiri. UU Tipikor dan UU PPTPPU sejatinya memiliki karakteristik yang sama sebagai tindak pidana ekonomi yang tidak hanya mengancam stabilitas perekonomian negara tetapi juga dapat membahayakan sendi-sendi kehidupan bermasyarakat, berbangsa, dan bernegara, tetapi memiliki formulasi alat bukti elektronik yang berbeda.

Adanya perbedaan formulasi terhadap alat bukti elektronik yang sama memunculkan ketertarikan untuk mengkaji dengan dua permasalahan. Permasalahan pertama adalah apakah yang mendasari perbedaan kebijakan formulasi alat bukti elektronik dalam UU Tipikor dan UU PPTPPU ditinjau dari ratio legis pembentuk undang-undang. Permasalahan kedua adalah bagaimanakah implikasi yuridis kebijakan formulasi alat bukti elektronik dalam UU Tipikor dan UU PPTPPU ditinjau dari pemenuhan minimal alat bukti dalam Pasal 183 KUHAP.

Metode penelitian ini menggunakan tipe penelitian yuridis normatif yaitu suatu penelitian yang difokuskan untuk mengkaji penerapan norma-norma dalam hukum positif yang berlaku. Adapun pendekatan masalah yang digunakan adalah dengan menggunakan pendekatan perundang-undangan (statute approach) yang dilakukan dengan menelaah semua undang-undang dan regulasi yang bersangkutan dengan isu hukum yang sedang ditangani ${ }^{3}$, dan pendekatan konseptual (conseptual approach) yang dilakukan dengan meneliti doktrin-doktrin yang berkembang dalam ilmu hukum yang bersangkutan dengan isu hukum yang sedang ditangani. ${ }^{4}$

\section{PERBEDAAN KEBIJAKAN FORMULASI ALAT BUKTI ELEKTRONIK DITINJAU DARI RATIO LEGIS PEMBENTUK UNDANG-UNDANG}

\section{A. Ratio Legis Alat Bukti Elektronik dalam Undang-Undang Tindak Pidana Korupsi}

UU Tipikor merupakan satu-satunya peraturan perundangan-undangan tindak pidana korupsi yang mengakui eksistensi alat bukti elektronik, sehingga ratio legis alat bukti elektronik dapat diketahui dengan meneliti proses pembentukan undang-undang ini. Menurut Dyah Ochtorina Susanti, untuk memahami ratio legis dari suatu ketentuan pasal dalam undang-undang terdapat beberapa langkah yang dilakukan ${ }^{5}$, pertama, menelusuri naskah akademik yang menyertai Rancangan Undang-Undang (RUU) dari

\footnotetext{
Peter Mahmud Marzuki, Penelitian Hukum Edisi Revisi (Jakarta: Prenadamedia Group, 2015), hlm. 133. Ibid, hlm. 135-136.

"DYAH PENELITIAN HUKUM", online: Issuu ‘https://issuu.com/dosenhukum/docs/dyah_penelitian _hukum>.
} 
lembaga yang mengajukan RUU tersebut. Kedua, menelusuri dan mengkaji risalah pembahasan undang-undang tersebut dalam sidang Dewan Perwakilan Rakyat (DPR).

RUU tentang Perubahan atas UU Tipikor merupakan RUU hasil inisiatif pemerintah yang resmi diserahkan untuk dibicarakan dalam Sidang DPR melalui surat Presiden Nomor R.10/RU/IV/2001 tanggal 24 April 2001. RUU ini tidak disertai dengan naskah akademik karena kewajiban membuat naskah akademik baru muncul dalam Undang-Undang Nomor 12 Tahun 2011 tentang Pembentukan Peraturan Perundangundangan (UU PPP). ${ }^{6}$ Dengan tidak adanya naskah akademik dalam RUU tersebut maka beranjak ke tahap selanjutnya yakni menelusuri dan mengkaji risalah pembahasan undang-undang tersebut dalam sidang DPR.

Masa persidangan pembahasan RUU Tipikor diikuti oleh berbagai fraksi, diantaranya Fraksi Kebangkitan Bangsa, Fraksi Reformasi, Fraksi TNI/POLRI, Fraksi Partai Bulan Bintang, Fraksi Kesatuan Kebangsaan Indonesia, Fraksi Perserikatan Daulatul Ummah, Fraksi Partai Demokrasi Kasih Bangsa, Fraksi Praktai Demokrasi Indonesia Perjuangan, Fraksi Partai Golongan Karya, Fraksi Partai Persatuan Pembangunan. ${ }^{7}$ Dalam Rapat Paripurna DPR tanggal 21 Mei 2001, pihak pemerintah hanya memberikan keterangan mengenai petunjuk alat bukti yang sah sebagaimana dimaksud dalam Pasal 188 ayat (2) KUHAP diperluas dengan menambah dua unsur sebagaimana dalam Pasal 26A yakni informasi elektronik dan dokumen elektronik tanpa menjelaskan alasan mendasar adanya pengakuan alat bukti elektronik tersebut serta konsekuensi hukum yang akan didapatkan dengan pengaturan tersebut. ${ }^{8}$ Lebih lanjut, dalam sidang Jawaban Pemerintah atas Pemandangan Umum Fraksi-Fraksi DPR tanggal 11 Juli 2001, Pemerintah hanya menjelaskan bahwa pengaturan perluasan alat bukti yang sah dalam bentuk petunjuk bertujuan agar pemberantasan tindak pidana korupsi dapat dilakukan secara intensif. ${ }^{9}$

Permasalahan pengaturan alat bukti elektronik bukan menjadi isu krusial dalam pembahasan undang-undang ini, terlihat dalam proses pemandangan umum hanya lima fraksi yang memberikan pendapatnya terkait eksistensi alat bukti elektronik dalam RUU ini. Dari lima fraksi yang memberikan pendapatnya terbagi lagi menjadi dua kelompok yakni kelompok yang setuju dan kelompok yang tidak setuju. Fraksi yang menyatakan persetujuannya diantaranya Fraksi Kebangkitan Rakyat, Fraksi Partai Bulan Bintang dan Fraksi Kesatuan Kebangsaan Indonesia. Fraksi Kebangkitan Rakyat menilai adanya perluasan alat bukti petunjuk ini perlu didukung atas dasar perkembangan teknologi informasi yang sedemikian cepat dan kompleks. ${ }^{10}$ Pendapat yang hampir sama disampaikan oleh Fraksi Partai Bulan Bintang bahwa perluasan alat bukti dilaksanakan untuk mengantisipasi perkembangan teknologi informasi pada saat

\footnotetext{
6 Undang-Undang Nomor 12 Tahun 2011 tentang Pembentukan Peraturan Perundang-undangan Pasal 43 ayat (3). Sekretariat Jenderal Dewan Perwakilan Rakyat Republik Indonesia, Naskah Proses Pembahasan Rancangan Undang-Undang Nomor 20 Tahun 2001 tentang Perubahan Atas Undang-Undang Nomor 31 Tahun 1999 tentang Pemberantasan Tindak Pidana Korupsi (2001), hlm. 1. 
ini yang dilakukan oleh para pelaku tindak pidana korupsi. ${ }^{11}$ Dukungan dengan catatan diberikan oleh Fraksi Kesatuan Kebangsaan Indonesia bahwa perluasan alat bukti dapat diberlakukan sepanjang dalam cara mendapatkannya tidak bertentangan dengan kaidah-kaidah hukum positif dan tidak bertentangan dengan moral Pancasila. ${ }^{12}$ Sedangkan pendapat penolakan diajukan oleh Fraksi Partai Demokrasi Kasih Bangsa dan Fraksi Partai Persatuan Pembangunan. Fraksi Partai Demokrasi Kasih Bangsa berpendapat bahwa alat bukti elektronik rawan terhadap rekayasa. ${ }^{13}$ Pendapat ini kemudian ditanggapi oleh Pemerintah bahwa untuk membuktikan data dalam bentuk rekaman atau dokumen tersebut asli atau tidak, pengadilan dapat menghadirkan ahli yang diperlukan. ${ }^{14}$ Penolakan diajukan pula oleh Fraksi Partai Persatuan Pembangunan yang berpendapat bahwa perluasan alat bukti petunjuk merupakan pengobrak-abrikan sistematika dalam perundang-undangan yang justru semakin mengaburkan suatu ketentuan hukum yang telah ada. ${ }^{15}$ Pendapat ini kemudian ditanggapi oleh Pemerintah, Pasal 26A tidak bermaksud untuk mengobrak-abrik sistematika dalam perundangundangan tetapi hanyalah perluasan alat bukti yang sah berupa petunjuk yang belum tercantum dalam KUHAP. ${ }^{16}$

Dengan demikian, terdapat dua alasan mendasar pentingnya alat bukti elektronik sebagai alat bukti untuk mengungkap tindak pidana korupsi.Pertama, sebagai bentuk antisipasi dari perkembangan teknologi dan informasi yang berpotensi dijadikan media untuk melakukan tindak pidana korupsi. Kedua, sebagai upaya intensif untuk mengungkap tindak pidana korupsi mengingat tindak pidana korupsi merupakan extraordinary crime yang menggunakan kecanggihan teknologi untuk memuluskan perbuatannya. Namun, sangat disayangkan dalam proses pembahasan Pasal 26A, Pemerintah dan fraksi-fraksi di DPR tidak membahas secara mendalam alasan dan konsekuensi yuridis dalam pengklasifikasian alat bukti elektronik sebagai perluasan dari alat bukti petunjuk. Apabila alasannya sebagai upaya intensif pemberantasan tindak pidana korupsi maka bukan menjadi masalah apabila alat bukti elektronik menjadi alat bukti yang berdiri sendiri bahkan dengan menambahkan alat bukti yang telah ada, maka alat bukti elektronik tersebut memiliki kekuatan yang setara dengan alat bukti lainnya. Dengan demikian, pilihan untuk menjadikan alat bukti elektronik sebagai perluasan petunjuk merupakan kebijakan terbuka (open legal policy) bagi pembentuk undang-undang, sehingga terdapat peluang yang besar untuk menjadikan alat bukti elektronik sebagai alat bukti yang berdiri sendiri apabila pembentuk undang-undang menghendaki hal tersebut.

Ibid, hlm. 62.
Ibid, hlm. 69.
Ibid, hlm. 79.
Ibid, hlm. 108.
Ibid, hlm. 101.
Ibid, hlm. 119. 


\section{B. Ratio Legis Alat Bukti Elektronik dalam Undang-Undang Tindak Pidana Pencucian Uang} Berbeda dengan UU Tipikor yang baru, mengakui alat bukti elektronik dalam undangundang yang terakhir, pengakuan alat bukti elektronik juga diatur dalam Pasal 38 UU PPTPPU, menyebutkan alat bukti pemeriksaan tindak pidana pencucian uang berupa alat bukti sebagaimana dimaksud dalam Hukum Acara Pidana; alat bukti lain berupa informasi yang diucapkan, dikirimkan, diterima, atau disimpan secara elektronik dengan alat optik atau yang serupa dengan itu; dan dokumen sebagaimana dimaksud dalam Pasal 1 angka 7. Pasal 1 angka 7 mendefinisikan dokumen adalah data, rekaman, atau informasi yang dapat dilihat, dibaca, dan/atau didengar, yang dapat dikeluarkan dengan atau tanpa bantuan suatu sarana, baik yang tertuang di atas kertas, benda fisik apapun selain kertas, atau yang terekam secara elektronik, termasuk tetapi tidak terbatas pada: tulisan, suara, atau gambar; peta, rancangan, foto, atau sejenisnya; huruf, tanda, angka, simbol, atau perforasi yang memiliki makna atau dapat dipahami oleh orang yang mampu membaca atau memahaminya. Pengakuan alat bukti elektronik dalam UU PPTPPU berdiri sendiri di samping alat bukti yang telah diakui dalam KUHAP. Dalam perkembangannya undang-undang ini diubah dengan Undang-Undang Nomor 25 Tahun 2003 namun ketentuan Pasal 38 tidak mengalami perubahan sehingga tetap menggunakan rumusan yang sama.

Tujuh tahun kemudian tepatnya tanggal 22 Oktober 2010 Pemerintah mengeluarkan Undang-Undang Nomor 8 Tahun 2010 tentang Pencegahan dan Pemberantasan Tindak Pidana Pencucian Uang (UU PPTPPU) sebagai pengganti undang-undang sebelumnya. Meskipun terdapat banyak penyesuaian dan penyempurnaan yang dilakukan terhadap undang-undang sebelumnya, namun ketentuan alat bukti elektronik tidak mengalami perubahan secara substansi hanya terdapat perubahan penempatan dan perumusan pasal. Dalam undang-undang ini pengaturan alat bukti yang sah dalam pembuktian tindak pidana pencucian uang terdapat dalam Pasal 73 yang menentukan bahwa alat bukti yang sah dalam pembuktian tindak pidana pencucian uang ialah alat bukti sebagaimana dimaksud dalam Hukum Acara Pidana; dan/atau alat bukti lain berupa informasi yang diucapkan, dikirimkan, diterima, atau disimpan secara elektronik dengan alat optik atau alat yang serupa optik dan dokumen. Dengan demikian, dapat diketahui bahwa pengakuan alat bukti elektronik telah diatur sejak Undang-Undang Nomor 15 Tahun 2002 dan tetap dipertahankan hingga Undang-Undang Nomor 8 Tahun 2010. Untuk mendapatkan pemahaman yang komprehensif mengenai ratio legis pengakuan alat bukti elektronik, maka dalam tulisan ini akan memaparkan ratio legis dari kedua undang-undang tersebut.

RUU tentang Tindak Pidana Pencucian Uang yang kemudian disahkan menjadi Undang-Undang Nomor 15 Tahun 2002 merupakan RUU hasil inisiatif Pemerintah yang resmi diserahkan untuk dibicarakan dalam Sidang DPR melalui surat Presiden Nomor R.01/PU/1/2001 tanggal 3 Januari 2001. RUU ini tidak disertai dengan naskah akademik karena kewajiban membuat naskah akademik baru muncul dalam (UU Pembentukan Peraturan Perundang-undangan). Dengan tidak adanya naskah akademik maka dalam tulisan ini akan beranjak ke tahap selanjutnya, yakni menelusuri dan 
mengkaji risalah pembahasan undang-undang tersebut dalam sidang DPR. Dalam keterangan Pemerintah dalam Rapat Paripurna DPR tanggal 18 Juni 2001, pihak Pemerintah hanya menjelaskan bahwa ${ }^{17}$ dalam RUU ini ditentukan alat bukti yang sah sebagaimana dimaksud dalam Pasal 184 KUHAP diperluas. Perluasan alat bukti yang sah tersebut dilakukan dengan menambah 2 (dua) unsur diantaranya alat bukti lain yang berupa informasi yang diucapkan, dikirim, diterima, atau disimpan secara elektronik dengan alat optik atau yang serupa dengan itu tetapi tidak terbatas pada electronic data interchange, surat elektronik, telegram, teleks, faksimile dan dokumen berupa tulisan, gambar, suara, peta, rancangan, foto.

Penjelasan lebih lanjut mengenai alasan Pemerintah menggunakan alat bukti elektronik sebagai alat bukti untuk penyidikan tindak pidana pencucian uang dapat diketahui dalam sidang Jawaban Pemerintah atas Pemandangan Umum Fraksi-Fraksi DPR tanggal 29 November 2001. Pengakuan alat bukti elektronik menjadi salah satu isu pokok dalam usaha pemberantasan tindak pidana pencucian uang, karena ${ }^{18}$ perkembangan teknologi canggih telah mendorong untuk mempertimbangkan penggunaan alat-alat bukti yang termuat dalam media atau perangkat elektronik, sehingga usaha pemberantasan tindak pidana pencucian uang dapat mencapai sasarannya lebih efektif, maka diperlukan perluasan alat bukti yang sah, dengan menambahdua unsur diantaranya alat bukti lain berupa informasi yang diucapkan, dikirim, diterima, atau disimpan secara elektronik dengan alat optik atau yang serupa dengan itu tetapi tidak terbatas electronic data interchange, surat elektronik, telegram, teleks, faksimile dan dokumen berupa tulisan, gambar, suara, peta, rancangan, foto, huruf, tanda, angka, atau data yang memiliki makna.

Pembahasan RUU tentang Tindak Pidana Pencucian Uang diikuti oleh berbagai fraksi, diantaranya Fraksi Partai Golongan Karya, Fraksi Partai Persatuan Pembangunan, Fraksi Kebangkitan Bangsa, Fraksi Reformasi, Fraksi TNI/POLRI, Fraksi Partai Bulan Bintang, Fraksi Kesatuan Kebangsaan Indonesia, Fraksi Perserikatan Daulatul Ummah, Fraksi Partai Demokrasi Kasih Bangsa, dan Fraksi Partai Demokrasi Indonesia Perjuangan. ${ }^{19}$ Dalam proses pemandangan umum fraksifraksi tidak ada yang membahas mengenai keberadaan alat bukti elektronik. Setelah melalui proses pembahasan dalam Rapat Paripurna Terbuka DPR (Pembicaraan Tingkat IV/Pengambilan Keputusan atas RUU) tanggal 25 Maret 2002 Pihak DPR menyerahkan rancangan akhir untuk disetujui sebagai undang-undang. Dalam rancangan akhir tersebut, Pasal 38 berbunyi sebagaimana pasal dalam UU PPTPPU bahwa alat bukti pemeriksaan tindak pidana pencucian uang berupa alat bukti sebagaimana dimaksud dalam Hukum Acara Pidana Dan alat bukti lain berupa informasi yang diucapkan, dikirimkan, diterima, atau disimpan secara elektronik

\footnotetext{
17 Sekretariat Jenderal Dewan Perwakilan Rakyat Republik Indonesia, Proses Pembahasan Rancangan Undang-Undang Tentang Tindak Pidana Pencucian Uang Buku I, hlm. 282.

$18 \quad$ Ibid, hlm. 102.

19 Ibid, hlm. 2.
} 
dengan alat optik atau yang serupa dengan itu; dan dokumen sebagaimana dimaksud dalam Pasal 1 angka 7.

Dengan demikian dalam pembahasan UU PPTPPU ini dapat diketahui bahwa pengakuan alat bukti elektronik didasarkan pada alasan pertama untuk mengikuti perkembangan teknologi canggih dan kedua, sebagai usaha pemberantasan tindak pidana pencucian uang dapat mencapai sasarannya dan dapat lebih efektif.

Saat ini UU PPTPPU yang masih berlaku adalah Undang-Undang Nomor 8 Tahun 2010. Undang-undang ini masih mempertahankan alat bukti elektronik sebagai alat bukti penyidikan tindak pidana pencucian uang. UU PPTPPU ini merupakan inisiasi pihak Pemerintah yang disampaikan kepada Ketua DPR melalui Surat Nomor R.13/Pres/2/2010 tanggal 18 Februari 2010. Dalam Rapat Kerja di hadapan DPR tanggal 5 Mei 2010. Menteri Hukum dan Hak Asasi Manusia menjelaskan pentingnya dilakukan perubahan UU PPTPPU ini didorong adanya beberapa kelemahan (loopholes) yang menghambat efektivitas penegakan hukum di bidang tindak pidana pencucian uang, namun ketentuan pengaturan alat bukti elektronik bukan menjadi isu pokok yang dibahas di dalamnya. ${ }^{20}$ Dengan tidak adanya pertimbangan baru dalam pengakuan alat bukti elektronik dalam Undang-Undang Nomor 8 Tahun 2010 maka digunakan pertimbangan dalam undang-undang sebelumnya.

Dengan demikian terdapat dua alasan mendasar pentingnya pengakuan alat bukti elektronik ini yakni karena dorongan perkembangan teknologi yang canggih dan upaya strategis untuk mempercepat pengungkapan tindak pidana pencucian uang. Dua alasan ini merupakan alasan yang juga digunakan oleh pembentuk UU Tipikor untuk mengakui alat bukti elektronik sebagai perluasan alat bukti petunjuk. Alasan yang sama namun memiliki pengakuan alat bukti elektronik yang berbeda menunjukkan tidak adanya kajian yang mendalam oleh pembentuk undang-undang dalam mengklasifikasikan alat bukti elektronik. Apabila konsisten dengan undang-undang terdahulu, seharusnya UU PPTPPU cukup menyalin konsep pengakuan alat bukti elektronik sebagai petunjuk sebagaimana dalam UU Tipikor. Tidak adanya alasan pengakuan alat bukti elektronik sebagai alat bukti yang berdiri sendiri dalam UU PPTPPU semakin meyakinkan bahwa pengaturan alat bukti elektronik merupakan kebijakan legislatif dari pembentuk undang-undang.

\section{IMPLIKASI YURIDIS KEBIJAKAN FORMULASI ALAT BUKTI ELEKTRONIK}

\section{A. Implikasi Yuridis Kebijakan Formulasi Alat Bukti Elektronik dalam Undang-Undang}

Tindak Pidana Korupsi

Alat bukti elektronik dalam UU Tipikor diakui sebagai perluasan alat bukti petunjuk, maka terikat dengan ketentuan Pasal 188 KUHAP yang mengatur tentang alat bukti petunjuk. Pasal 188 mendefinisikan "Petunjuk" adalah perbuatan, kejadian atau

20 Sekretariat Jenderal Dewan Perwakilan Rakyat Republik Indonesia, Risalah Rancangan Undang-Undang tentang Pencegahan dan Pemberantasan Tindak Pidana Pencucian Uang (2010), hlm. 9. 
keadaan, yang karena persesuaiannya, baik antara yang satu dengan yang lain maupun dengan tindak pidana itu sendiri, menandakan bahwa telah terjadi suatu tindak pidana dan siapa pelakunya. Petunjuk hanya dapat diperoleh dari keterangan saksi, surat, dan keterangan terdakwa. Lebih lanjut, penilaian atas kekuatan pembuktian dari suatu petunjuk dalam setiap keadaan tertentu dilakukan oleh hakim dengan arif lagi bijaksana, setelah ia mengadakan pemeriksaan dengan penuh kecermatan dan keseksamaan berdasarkan hati nuraninya.

Alat bukti petunjuk berbeda dengan alat bukti lainnya. Alat bukti petunjuk tidak diperiksa di persidangan karena alat bukti petunjuk berbentuk abstrak. Apabila alat bukti lain seperti keterangan saksi, keterangan ahli, surat bahkan keterangan terdakwa berasal dari pihak yang bersangkutan secara langsung, tidak demikian dengan alat bukti petunjuk yang justru diperoleh dari alat bukti lainnya seperti keterangan saksi, surat dan keterangan terdakwa. Dengan demikian, alat bukti petunjuk disebut juga alat bukti tidak langsung (indirect bewijs). Adami Chazawi mengatakan bahwa alat bukti petunjuk ini tidak mungkin diperoleh dan digunakan sebelum digunakannya alat-alat bukti lain. Alat bukti petunjuk tidak mungkin berdiri sendiri, tetapi bergantung pada alat-alat bukti lain yang telah dipergunakan atau diajukan oleh Jaksa Penuntut Umum (JPU) dan juga oleh penasihat hukum. ${ }^{21}$ Hari Sasangka dan Lily Rosita menilai bahwa karena adanya syarat yang satu dengan yang lain harus terdapat kesesuaian, dengan demikian berakibat sekurang-kurangnya perlu ada dua petunjuk untuk memperoleh bukti yang sah atau sebuah alat bukti petunjuk dengan satu buah bukti lain ada kesesuaian dalam keseluruhan yang dapat menimbulkan alat bukti. ${ }^{22}$

Eddy O.S. Hiariej mengatakan petunjuk adalah circumtantial evidence atau bukti tidak langsung yang bersifat pelengkap atau accesories evidence. Artinya, petunjuk bukanlah alat bukti mandiri, namun merupakan alat bukti sekunder yang diperoleh dari alat bukti primer, dalam hal ini adalah keterangan saksi, surat, dan keterangan terdakwa. ${ }^{23} \mathrm{M}$. Yahya Harahap mengatakan, alat bukti petunjuk tidak akan pernah ada selama tidak ada alat bukti yang lain yang menjadi sumber kelahirannya. ${ }^{24}$ Dengan demikian, alat bukti petunjuk sebagai alat bukti sekunder membawa konsekuensi bahwa alat bukti ini bergantung pada adanya kesesuaian dengan alat bukti petunjuk lainnya, sehingga alat bukti petunjuk tidak bernilai apabila tidak menunjukkan adanya kesesuaian dengan alat-alat bukti yang lain.

Menurut Adami Chazawi, alat bukti petunjuk baru digunakan dalam hal apabila dari alat-alat bukti yang ada belum dapat membentuk keyakinan hakim tentang terjadinya tindak pidana dan keyakinan terdakwa bersalah melakukan tindak pidana. Terdapat dua kemungkinan hakim ini belum dapat membentuk keyakinan yaitu belum memenuhi syarat minimal pembuktian yakni sekurang-kurangnya dua alat bukti atau

${ }^{21}$ Adami Chazawi, Hukum Pidana Korupsi di Indonesia (Edisi Revisi) (Bandung: Alumni, 2016), hlm. 361.

22 Hari Sasangka \& Lily Rosita, Komentar Kitab Undang-Undang Hukum Acara Pidana (KUHAP) Buku Pedoman Mahasiswa dan Praktisi (Bandung: Mandar Maju, 2003), hlm. 364.

23 Eddy OS Hiariej, Teorie Hukum Pembuktian (Jakarta: Erlangga, 2012), hlm. 110-1ll.

24 M Yahya Harahap, Pembahasan Permasalahan dan Penerapan KUHAP Pemeriksaan Sidang Pengadilan, Banding, Kasasi dan Peninjauan Kembali, kedua ed (Jakarta: Sinar Grafika, 2012), hlm. 317. 
sudah ada dua alat bukti tetapi hakim belum mendapatkan keyakinan tentang terjadinya tindak pidana atau terdakwa selaku pembuatnya. ${ }^{25}$ Sejalan dengan Adami Chazawi, M. Yahya Harahap yang dikutip R. Wiyono mengemukakan bahwa alat bukti petunjuk dapat digunakan hanya dalam keadaan penting dan mendesak, sehingga hakim harus lebih dahulu benar-benar memeriksa dan mempergunakan alat bukti yang lain. Selama alat bukti yang lain masih mencukupi, hakim jangan segera berpaling mencari alat bukti petunjuk.

Pasal 188 ayat (3) KUHAP, alat bukti petunjuk merupakan otoritas penuh dan subjektivitas hakim yang memeriksa perkara tersebut. Hakim dalam mengambil kesimpulan tentang pembuktian sebagai suatu petunjuk haruslah menghubungkan alat bukti yang satu dengan alat bukti lainnya dan memiliki kesesuaian antara satu sama lainnya. Dengan demikianAdami Chazawi mengatakan bahwa alat bukti petunjuk merupakan alat bukti bentukan hakim yang dominan subjektivitas hakim dalam membentuknya. ${ }^{26}$ Penilaian atas kekuatan pembuktian petunjuk bersifat subjektif karena hanya didasarkan pada kearifan, kebijaksanaan dan hati nurani hakim. Di sisi lain, A. Karim Nasution menilai dalam mempergunakan alat bukti petunjuk, tugas hakim akan lebih sulit karena harus mencari hubungan antara perbuatan, kejadian atau keadaan, menarik kesimpulan serta mengombinasikan akibat-akibatnya dan akhirnya sampai pada suatu keputusan terbukti atau tidaknya sesuatu yang didakwakan. ${ }^{27}$ Keberadaan alat bukti petunjuk di satu sisi menjadi alat bukti penguat untuk menemukan kebenaran materiil namun di sisi lain hakim dibebani kewajiban untuk menghubungkan antara alat-alat bukti yang ada sebagai sumber perolehan alat bukti petunjuk.

Perluasan alat bukti petunjuk dalam UU Tipikor membawa konsekuensi bahwa sumber untuk membentuk alat bukti petunjuk tidak hanya terbatas pada keterangan saksi, surat dan keterangan terdakwa tetapi juga telah memasukkan alat bukti elektronik di dalamnya. Dengan memasukkan alat bukti elektronik sebagai sumber perolehan alat bukti petunjuk maka alat bukti elektronik memiliki legalitas sebagai alat bukti yang sah. Secara formal alat bukti elektronik sebagai perluasan alat bukti petunjuk dalam Pasal 26A memiliki kedudukan yang sejajar dengan tiga alat bukti lain yakni keterangan saksi, surat dan keterangan terdakwa dalam hal membentuk alat bukti petunjuk. ${ }^{28}$ Keputusan mengakui alat bukti elektronik sebagai alat bukti yang sah merupakan langkah yang tepat mengingat di era perkembangan teknologi dan informasi yang ada berdampak secara langsung terhadap kecanggihan modus operandi tindak pidana korupsi. Dengan menjadikan alat bukti elektronik sebagai alat bukti yang sah dapat mempercepat proses pengungkapan tindak pidana korupsi guna menemukan kebenaran materiil.

Adami Chazawi, Hukum Pembuktian Tindak Pidana Korupsi (Bandung: Alumni, 2006), hlm. 75-76.

26 Ibid, hlm. 73.

27 Hari Sasangka \& Lily Rosita, Hukum Pembuktian Dalam Perkara Pidana (Bandung: Mandar Maju, 2003), hlm. 79.

28 Chazawi, supra note 25, hlm. 105. 
Alat bukti elektronik yang diakui sebagai perluasan alat bukti petunjuk menyebabkan alat bukti elektronik memiliki konstruksi hukum yang sama sebagaimana alat bukti petunjuk lainnya. Alat bukti elektronik sebagai alat bukti petunjuk memiliki kedudukan yang lebih lemah dari alat bukti lain yakni keterangan saksi, surat, keterangan ahli maupun keterangan terdakwa. Alat bukti elektronik dalam pembuktiannya hanya dapat digunakan dalam keadaan yang sangat mendesak apabila hakim belum mendapat alat bukti minimum atau belum mendapatkan keyakinan atas suatu tindak pidana. Alat bukti elektronik sebagai alat bukti petunjuk juga menjadikan alat bukti elektronik sebagai alat bukti tidak langsung (circumtantial evidence) yang bersifat pelengkap (accesories evidence) yang baru dapat digunakan apabila memiliki kesesuaian dengan alat bukti petunjuk lainnya. Di sisi lain, sebagai konsekuensiya alat bukti petunjuk hanya didasarkan pada penilaian hakim, maka keputusan untuk menyandarkan putusannya terhadap alat bukti elektronik menjadi otoritas penuh dari hakim. Dengan demikian, apabila ditinjau dari pemenuhan asas minimum pembuktian alat bukti elektronik baru akan bernilai sebagai satu alat bukti yang sah ketika terdapat kesesuaian dengan alat bukti pembentuk alat bukti petunjuk, sehingga tidak dapat langsung digunakan untuk membuktikan suatu tindak pidana.

\section{B. Implikasi Yuridis Kebijakan Formulasi Alat Bukti Elektronik dalam Undang-Undang Tindak} Pidana Pencucian Uang

Pasal 73 UU PPTPPU mengakui dua jenis alat bukti yakni pertama, alat bukti sebagaimana dimaksud dalam Hukum Acara Pidana, dan kedua, alat bukti lain berupa informasi yang diucapkan, dikirimkan, diterima, atau disimpan secara elektronik dengan alat optik atau alat yang serupa optik dan Dokumen. Apabila dirinci maka alat bukti yang sah dalam pembuktian tindak pidana Pencucian Uang diantaranya keterangan saksi, keterangan ahli, Surat, Petunjuk, keterangan terdakwa, dan/atau alat bukti lain berupa informasi yang diucapkan, dikirimkan, diterima, atau disimpan secara elektronik dengan alat optik atau alat yang serupa optik, dan dokumen. Kedudukan alat bukti elektronik sebagai alat bukti yang sah dalam pembuktian tindak pidana pencucian uang bersifat menambahkan alat bukti yang telah diakui dalam KUHAP, sehingga alat bukti tersebut berjumlah menjadi tujuh.

Alat bukti elektronik dalam UU PPTPPU memiliki kedudukan yang kuat karena setara dengan alat bukti lain dalam KUHAP. Dalam sistem pembuktian menurut KUHAP tidak mengenal kekuatan pembuktian yang didasarkan pada urut-urutan alat buktinya artinya daya pengaruh atau kekuatan alat-alat bukti yang satu tidak lebih kuat daripada yang lain, ${ }^{29}$ meskipun alat bukti elektronik merupakan alat bukti yang baru dan berada dalam urutan terakhir tetapi kekuatan pembuktiannya tidak lebih lemah dari alat bukti lainnya. Alat bukti elektronik yang menambahkan alat bukti yang sah dalam KUHAP merupakan langkah yang baru dalam kebijakan hukum acara pidana karena secara langsung memperbanyak alat bukti yang sah. Hal ini berbeda dengan

29 Chazawi, supra note 21, hlm. 359. 
eksistensi alat bukti elektronik dalam UU Tipikor yang hanya memperluas alat bukti petunjuk.

Suatu alat bukti elektronik harus memenuhi syarat materiil dan syarat formil agar dapat digunakan dalam proses persidangan. Syarat materiil alat bukti elektronik berhubungan dengan sisi substansi maupun prosedural diperolehnya alat bukti tersebut. Secara substansi alat bukti elektronik harus dapat diakses, ditampilkan, dijamin keutuhannya, dan dapat dipertanggungjawabkan sehingga menerangkan suatu keadaan. $^{30}$ Syarat materiil lainnya yaitu suatu alat bukti elektronik juga harus menggunakan sistem elektronik sesuai dengan ketentuan yang diatur dalam UndangUndang Nomor 11 Tahun 2008 tentang Informasi dan Transaksi Elektronik sebagaimana telah diubah dengan Undang-Undang Nomor 19 Tahun 2016 tentang Perubahan Atas Undang-Undang Nomor 11 Tahun 2008 Tentang Informasi dan Transaksi Elektronik (UU ITE).

Terdapat beberapa persyaratan minimum suatu sistem elektronik diantaranya ${ }^{31}$ dapat menampilkan kembali informasi elektronik dan/atau dokumen elektronik secara utuh sesuai dengan masa retensi yang ditetapkan dengan peraturan perundangundangan, dapat melindungi ketersediaan, keutuhan, keotentikan, kerahasiaan, dan keteraksesan informasi elektronik dalam penyelenggaraan sistem elektronik tersebut, dapat beroperasi sesuai dengan prosedur atau petunjuk dalam penyelenggaraan sistem elektronik tersebut, dilengkapi dengan prosedur atau petunjuk yang diumumkan dengan bahasa, informasi, atau simbol yang dapat dipahami oleh pihak yang bersangkutan dengan penyelenggaraan sistem elektronik tersebut, dan memiliki mekanisme yang berkelanjutan untuk menjaga kebaruan, kejelasan, dan kebertanggungjawaban prosedur atau petunjuk.

Syarat formil alat bukti elektronik yaitu alat bukti elektronik tersebut bukan merupakan dokumen atau surat yang menurut perundang-undangan harus dalam bentuk tertulis. Apabila ditemukan ada pihak yang mengajukan dokumen elektronik dalam bentuk tertulis, maka hakim harus menolaknya, sampai pihak yang mengajukan itu mampu menghadirkan alat bukti surat yang otentik. ${ }^{32}$ Dalam perkembangannya melalui Putusan MK Nomor 20/PUU-XIV/2016 memberikan prasyarat bahwa alat bukti elektronik dilakukan dalam rangka penegakan hukum atas permintaan kepolisian, kejaksaan, dan/atau institusi penegak hukum lainnya yang ditetapkan berdasarkan undang-undang. ${ }^{33}$ Pascaputusan ini maka alat bukti elektronik yang dihadirkan dalam persidangan harus atas dasar permintaan institusi penegak hukum, sehingga alat bukti yang tidak memenuhi syarat tersebut dapat dikesampingkan oleh

30 Barda Nawawi Arief, Tindak Pidana Mayantara (Perkembangan Kebijakan Cyber Crime di Indonesia (Jakarta: RajaGrafindo Perkasa, 2006), hlm. 217.

31 Undang-Undang Nomor 11 Tahun 2008 tentang Informasi dan Transaksi Elektronik (Undang-Undang Nomor 11 Tahun 2008 tentang Informasi dan Transaksi Elektronik) Pasal 16.

32 Hendi Suhendi, Pentingnya Bukti Elektronik dalam Persidangan Pidana (Jurnal Bina Adhyaksa Volume 7 Nomor 1, 2016) hlm. 24.

33 Putusan Mahkamah Konstitusi Nomor 20/PUU-XIV/2016 (Putusan Mahkamah Konstitusi Nomor 20/PUUXIV/2016), hlm. 97-98. 
hakim. Syarat materiil dan syarat formil harus terpenuhi secara kumulatif agar suatu alat bukti elektronik tersebut dapat bernilai dalam proses peradilan.

Alat bukti elektronik yang dapat dinilai dalam persidangan tidak hanya telah memenuhi syarat materiil dan syarat formil, tetapi juga terikat dengan teori hukum pembuktian yang mengajarkan bahwa agar suatu alat bukti dapat dipakai sebagai alat bukti di pengadilan diperlukan syarat-syarat diantaranya, ${ }^{34}$ diperkenankan oleh undang-undang untuk dipakai sebagai alat bukti; Reability, yakni alat bukti tersebut dapat dipercaya keabsahannya; Necessity, yakni alat bukti tersebut memang diperlukan untuk membuktikan suatu fakta; dan Relevance, yakni alat bukti tersebut mempunyai relevansi dengan fakta yang akan dibuktikan.

Eksistensi alat bukti elektronik dalam UU PPTPPU sebagai penambahan alat bukti dalam KUHAP bersifat mandiri yang tidak terikat dengan alat bukti lain dalam penggunaannya menyebabkan alat bukti elektronik dapat dijadikan sebagai alat bukti permulaan atau bahkan alat bukti utama untuk mengungkap suatu tindak pidana. Eksistensi ini berpengaruh terhadap prinsip minimum pembuktian. Dengan konstruksi Pasal 183 ayat (1) KUHAP keberadaan alat bukti elektronik telah memenuhi syarat sebagai satu alat bukti yang sah untuk menjatuhkan pidana, sehingga hanya diperlukan satu alat bukti lagi untuk memenuhi minimal dua alat bukti tersebut, misalnya dengan alat bukti elektronik ditambah dengan keterangan ahli sudah dapat memenuhi prinsip minimum pembuktian. Dengan demikian eksistensi alat bukti elektronik sebagai penambahan alat bukti dalam KUHAP akan mempercepat proses pembuktian pidana terutama tindak pidana yang telah menggunakan kecanggihan teknologi sebagai media utamanya.

\section{Rekonsepsi Eksistensi Alat Bukti Elektronik dalam Pembuktian Tindak Pidana}

Keberadaan alat bukti elektronik merupakan konsekuensi dari berkembangnya kecanggihan teknologi informasi dan komunikasi yang digunakan dalam tindak pidana. Untuk mengantisipasi potensi penyalahgunaan teknologi informasi maka Pemerintah menerbitkan UU ITE sebagai infrastruktur hukum. Pasal 5 ayat (1) UU ITE secara tegas mengatur keabsahan alat bukti elektronik sebagai alat bukti yang sah, sedangkan Pasal 5 ayat (2) menyatakan bahwa alat bukti elektronik merupakan perluasan dari alat bukti yang sah sesuai dengan Hukum Acara yang berlaku di Indonesia. Dalam Penjelasan Pasal 5 ayat (1) menyatakan bahwa keberadaan informasi elektronik dan/atau dokumen elektronik mengikat dan diakui sebagai alat bukti yang sah untuk memberikan kepastian hukum terhadap penyelenggaraan sistem elektronik dan transaksi elektronik, terutama dalam pembuktian dan hal yang berkaitan dengan perbuatan hukum yang dilakukan melalui sistem elektronik. Kemudian penjelasan Pasal 5 ayat (2) menyatakan khusus untuk informasi elektronik dan/atau dokumen elektronik berupa hasil intersepsi atau penyadapan atau perekaman yang merupakan bagian dari penyadapan harus dilakukan dalam rangka penegakan hukum atas

34 Munir Fuady, Teori Hukum Pembuktian (Pidana dan Perdata) (Bandung: Citra Aditya Bakti, 2012), hlm. 4. 
permintaan kepolisian, kejaksaan, dan/atau institusi lainnya yang kewenangannya ditetapkan berdasarkan undang-undang.

Dengan mencermati pasal-pasal tersebut dapat diketahui bahwa UU ITE memberikan kepastian hukum bahwa alat bukti elektronik merupakan alat bukti yang sah bersifat mengikat dan diakui sebagai alat bukti terhadap perbuatan hukum yang dilakukan melalui sistem elektronik. Sistem elektronik menurut Pasal 1 angka (5) UU ITE adalah serangkaian perangkat dan prosedur elektronik yang berfungsi mempersiapkan, mengumpulkan, mengolah, menganalisis, menyimpan, menampilkan, mengumumkan, mengirimkan, dan/atau menyebarkan informasi elektronik. Sistem elektronik adalah komputer dalam arti luas, yang tidak hanya mencakup perangkat keras dan perangkat lunak komputer, tetapi juga mencakup jaringan telekomunikasi dan/atau sistem komunikasi elektronik. ${ }^{35}$ Sistem elektronik tidak dapat diartikan secara sempit sebagai perangkat komputer secara fisik tetapi juga termasuk di dalamnya perangkat lunak, jaringan telekomunikasi maupun sistem komunikasi elektronik.

Secara sederhana dapat dimaknai bahwa segala perangkat apapun yang dapat menghasilkan informasi elektronik dapat dikategorikan sebagai sistem elektronik, sehingga pengakuan keabsahan alat bukti elektronik dalam penjelasan pasal tersebut tidak hanya berlaku terhadap pemeriksaan tindak pidana yang diatur dalam UU ITE semata tetapi juga berlaku terhadap semua perbuatan hukum yang dilakukan melalui sistem elektronik, baik tindak pidana umum maupun tindak pidana khusus. Pasal 5 ayat (2) UU ITE menegaskan bahwa alat bukti elektronik merupakan perluasan dari alat bukti yang sah sesuai dengan hukum acara yang berlaku di Indonesia. Permasalahannya pasal tersebut tidak menjelaskan apa yang dimaksud dengan frasa "perluasan dari alat bukti yang sah". Penjelasan Pasal 5 ayat (2) UU ITE hanya berisi tentang syarat formil diakui alat bukti elektronik berupa hasil intersepsi atau penyadapan atau perekaman. Penjelasan pasal 5 ayat (2) UU ITE merupakan pengakomodasian konstitusional bersyarat yang diberikan dalam Putusan MK Nomor 20/PUU-XIV/2016.

Perbedaan eksistensi alat bukti elektronik dalam UU Tipikor dan UU PPTPPU menjadi konsekuensi nyata dari ketidakjelasan makna "perluasan dari alat bukti yang sah" dalam Pasal 5 ayat (2) UU ITE. Pengakuan alat bukti elektronik tanpa konsepsi yang jelas menimbulkan permasalahan terhadap kedudukan serta nilai pembuktian alat bukti elektronik tersebut. Apabila mencermati Pasal 44 UU ITE dalam pembuktian tindak pidana di bidang informasi dan transaksi elektronik menganut konsep "perluasan dari alat bukti yang sah" dengan menambahkan alat bukti yang telah diakui sebelumnya dalam hukum acara pidana umum karena dalam Pasal 44 UU ITE menempatkan alat bukti elektronik setara dengan alat bukti sebagaimana dimaksud dalam KUHAP. Namun konsep penambahan alat bukti yang sah ini tidak serta merta dapat diterapkan terhadap tindak pidana lain karena ketentuan ini berlaku khusus terhadap penyidikan tindak pidana dalam UU ITE. Asas lex specialis derogat legi generalis

35 Maskun, supra note 2, hlm. 30. 
(undang-undang yang bersifat khusus mengesampingkan undang-undang yang bersifat umum) juga tidak dapat digunakan karena asas ini hanya berlaku terhadap dua undang-undang yang mengatur hal yang sama namun saling bertentangan sehingga asas ini tidak dapat diterapkan terhadap semua undang-undang khusus. ${ }^{36}$

Tidak adanya makna yang baku terhadap frasa "perluasan dari alat bukti yang sah" menyebabkan perbedaan pemahaman dan perdebatan di kalangan para ahli. Terdapat dua perbedaan pemahaman alat bukti elektronik sebagai perluasan alat bukti yang sah. Pertama, memperluas jumlah alat bukti yang diatur dalam KUHAP, artinya alat bukti elektronik bersifat menambahkan alat bukti yang telah diakui dalam KUHAP sehingga terdapat tujuh jenis alat bukti yang sah dalam pembuktian tindak pidana yaitu keterangan saksi, keterangan ahli, surat, petunjuk, keterangan terdakwa, informasi dan/atau dokumen elektronik dan hasil cetaknya. Pendapat ini didukung oleh Eddy O.S. Hiariej ${ }^{37}$ dan Edmon Makarim ${ }^{38}$. Jenis perluasan ini yang digunakan dalam pengakuan alat bukti dalam UU PPTPPU. Kedua, memperluas cakupan alat bukti yang diatur KUHAP, artinya alat bukti elektronik dikategorikan sebagai bagian dari alat bukti yang telah diakui dalam KUHAP, misalnya dokumen hasil cetak alat bukti elektronik yang diakui sebagai alat bukti surat dan informasi elektronik dan/atau dokumen elektronik diakui sebagai bagian sumber perolehan alat bukti petunjuk. Pendapat ini didukung oleh Josua Sitompul ${ }^{39}$, Kejaksaan Republik Indonesia ${ }^{40}$ dan M. Yahya Harahap ${ }^{41}$. Jenis perluasan ini yang digunakan dalam pengakuan alat bukti dalam UU Tipikor. Permasalahan kedudukan alat bukti elektronik merupakan permasalahan yang harus segera ditemukan solusinya karena perbedaan kedudukan alat bukti berimplikasi terhadap nilai kekuatan pembuktiannya sebagaimana dalam UU Tipikor dan UU PPTPPU.

Secara historis pengakuan alat bukti elektronik diawali dengan diterbitkannya Surat Mahkamah Agung kepada Menteri Kehakiman Nomor 39/TU/88/102/Pid tanggal 14 Januari 1988 yang menyatakan bahwa microfilm atau microfiche dapat dipergunakan sebagai alat bukti yang sah dalam perkara pidana di pengadilan menggantikan alat bukti surat, dengan catatan microfilm tersebut sebelumnya dijamin keasliannya yang

36 Fikri \& Budiman, Penerapan Asas Lex Specialis Derogat Legi Generalis dan Penyelesaian Sengketa Ekonomi dalam Undang-Undang Perbankan Syariah di Indonesia (Jurnal Al-Ihkam Volume 12 Nomor 1, 2017), hlm. 158.

37 Nur Laili Isma \& Arima Koyimatun, Kekuatan Pembuktian Alat Bukti Informasi Elektronik Pada Dokumen Elektronik serta Hasil Cetaknya dalam Pembuktian Tindak Pidana (Jurnal Penelitian Hukum Volume 1 Nomor 2, 2014), hlm. 112.

38 Edmon Makarim, Pengantar Hukum Telematika: Suatu Kompilasi (Jakarta: Raja Grafindo Persada, 2005), hlm. 457.

39 Josua Sitompul, Cyberspace, Cybercrimes, Cyberlaw : Tinjauan Aspek Hukum Pidana (Jakarta: Tatanusa, 2012).

40 "Kejaksaan Republik Indonesia", online: 〈https://kejaksaan.go.id/unit_kejaksaan.php?idu=28\& $\bullet i d s u=$ 35\& $<i d=4183$.

41 Bambang Tjatur Iswanto \& Nurul Maghfiroh, Alat Bukti dan Masalah yang Timbul dalam Perjanjian Sejak Pelaksanaan UU ITE (TRANFORMASI Jurnal Informasi \& Pengembangan IPTEK Volume 11 Nomor 1 , 2015), hlm. 43. 
dapat ditelusuri kembali dari registrasi maupun berita acara. ${ }^{42}$ Microfilm ini kemudian diatur dalam Undang-Undang Nomor 8 Tahun 1997 tentang Dokumen Perusahaan (UU Dokumen Perusahaan) yang berfungsi untuk menyimpan dokumen sebuah perseroan antara lain akta pendiriannya yang dihasilkan secara elektronik. Dalam praktiknya, alat bukti elektronik menjadi alat bukti yang penting dalam pembuktian suatu tindak pidana, misalnya pemeriksaan saksi dengan menggunakan teleconference pernah dipergunakan dalam proses persidangan terpidana terorisme Abu Bakar Baasyir, rekaman video kasus artis Ariel dan pornografi, CCTV dalam kasus kopi sianida Jesica, termasuk sistem layanan pesan singkat sms (short massage sytem) kasus hukum korupsi Angelina Sondakh terkait kasus korupsi Wisma Atlet Hambalang, hingga screenshoots percakapan whatsapps Habieb Rizieq dan lain-lain. ${ }^{43}$

Alat bukti elektronik merupakan alat bukti yang penting dalam membuktikan suatu tindak pidana yang dilakukan melalui teknologi informasi yang ada. Dengan demikian, alat bukti elektronik harus diakui eksistensinya sebagai alat bukti yang berdiri sendiri dan tidak dijadikan sebagai perluasan sumber perolehan alat bukti petunjuk karena alat bukti elektronik dapat menjadi alat bukti utama dan pertama dalam pembuktian sedangkan apabila eksistensinya hanya sebagai alat bukti petunjuk maka alat bukti elektronik hanya digunakan apabila alat bukti yang lain belum memenuhi syarat minimum atau belum adanya keyakinan hakim. Kedudukan alat bukti elektronik sebagai petunjuk justru dapat menyulitkan hakim apabila tindak pidana yang ada dilakukan dengan minim saksi karena dilakukan dalam dunia maya, selain itu dengan menjadikan alat bukti elektronik berdiri sendiri maka memudahkan hakim dalam memenuhi syarat minimum dalam menjatuhkan pidana. Di sisi lain, alat bukti petunjuk merupakan alat bukti yang telah dihapus dan tidak dikenal dalam KUHAP yang ada di dunia. ${ }^{44}$ Di Belanda, alat bukti petunjuk telah dihapus puluhan tahun lalu dan diganti dengan alat bukti Pengamatan Hakim. ${ }^{45}$ Penentangan keberadaan alat bukti petunjuk juga dikemukakan para ahli, diantaranya Van Bemmelen ${ }^{46}$, P.A.F. Lamintang $^{47}$ dan Wirjono Prodjodikoro ${ }^{48}$.

Pengakuan alat bukti elektronik sebagai alat bukti yang sah secara berdiri sendiri seharusnya dimasukkan dalam KUHAP karena pada dasarnya KUHAP menjadi hukum acara pidana yang mengikat seluruh proses peradilan tindak pidana, namun karena

42 Sri Ayu Astuti, Perluasan Penggunaan Bukti Elektronik (Evidence of Electronic) Terkait Ketentuan Alat Bukti Sah atas Perbuatan Pidana di Ruang Mayantara (Cyberspace) (Paraguyung Law Journal Volume 1 Nomor 1, 2017), hlm. 52.

$43 \mathrm{Ibid}, \mathrm{hlm} .47$.

44 Tim di bawah Pimpinan Didik Endro Puwoleksono, Naskah Akademik Rancangan Undang-Undang tentang Hukum Acara Pidana (Jakarta: Badan Pembinaan Hukum Nasional Departemen Hukum dan Hak Asasi Manusia RI., 2012), hlm. 96.

45 Al Wisnubroto \& G Widiartana, Pembaharuan Hukum Acara Pidana (Bandung: Citra Aditya Bakti, 2005), hlm. 103.

46 Sasangka \& Rosita, supra note 27, hlm. 75-76.

47 PAF Lamintang \& Theo Lamintang, Pembahasan KUHAP Menurut Ilmu Pengetahuan o Yurisprudensi (Jakarta: Sinar Grafika, 2013), hlm. 430.

48 Chazawi, supra note $25, \mathrm{hlm} .73$. 
ketidakmampuan KUHAP untuk mengikuti perkembangan zaman maka undangundang pidana khusus mengatur hukum acaranya sendiri untuk menutupi kelemahan KUHAP, salah satunya terkait pengakuan alat bukti yang sah. Alat bukti elektronik yang diakui dalam KUHAP memberikan kepastian hukum terkait kedudukan dan nilai kekuatan hukumnya sehingga tidak ada lagi disparitas pengakuan alat bukti elektronik dalam proses pembuktian tindak pidana umum dan tindak pidana khusus.

Mengakui alat bukti elektronik sebagai alat bukti yang berdiri sendiri menunjukkan komitmen terhadap pentingnya alat bukti elektronik guna mengungkap suatu tindak pidana, karena pada dasarnya dalam praktik peradilan hakim sudah menerima dokumen elektronik sebagai alat bukti. Kasus-kasus pidana yang berhubungan dengan perbankan umumnya rekening koran atau dokumen apapun yang berisikan data nasabah berikut laporan keuangannya dihadirkan sebagai alat bukti surat, padahal rekening koran sebenarnya adalah cetakan (print out) laporan keuangan nasabah yang dalam bentuk aslinya berupa dokumen elektronik (file komputer). Seluruh proses pembuktian kasus-kasus perbankan dalam kaitannya dengan dana nasabah sangat mustahil didasarkan pada dokumen yang aslinya berbentuk kertas. Kalaupun ada dokumen berbentuk kertas maka itu hanyalah cetakan file komputer pada bank yang bersangkutan. ${ }^{49}$ Dengan demikian alat bukti yang banyak digunakan dalam pengungkapan tindak pidana korupsi dan tindak pidana pencucian uang sejatinya berasal dari media elektronik yang kemudian dicetak ke kertas, maka menjadikan alat bukti elektronik sebagai alat bukti yang sah semakin memperkuat legalitas alat bukti yang digunakan dalam pembuktian tindak pidana.

Alat bukti elektronik yang dihasilkan oleh suatu sistem elektronik bersifat netral, yakni sepanjang sistem tersebut berjalan baik tanpa gangguan, input dan output yang dihasilkan terlahir sebagaimana mestinya. ${ }^{50}$ Alat bukti elektronik memang berpotensi terjadi manipulasi, namun bukan berarti alat bukti tertulis menjamin tidak akan terjadi adanya pemalsuan justru alat bukti tertulis lebih berpotensi disalahgunakan karena tidak adanya mekanisme pengecekan keasliannya secara teruji. Berbeda dengan alat bukti elektronik, adanya standar sistem komputer yang digunakan untuk menghasilkan alat bukti elektronik justru menjadi langkah awal untuk memastikan data tersebut benar dan dapat dijadikan sebagai alat bukti yang sah di persidangan. Di samping itu, untuk menentukan suatu data elektronik sah dan dapat dipertanggungjawabkan secara hukum juga membutuhkan peran seorang ahli dalam memberikan suatu penjelasan dalam persidangan. Dengan prosedur ini maka kebenaran data elektronik tersebut tidak perlu diragukan lagi.

Menjadikan alat bukti elektronik sebagai alat bukti yang sah memiliki beberapa keuntungan. Pertama, alat bukti elektronik yang diakui secara legalitas dalam KUHAP memberikan kepastian hukum kepada hakim untuk menjatuhkan putusan, sehingga tidak ada pihak-pihak yang menilai hakim telah salah menggunakan hukum dengan

49 Dikdik M Arief Mansur \& Elisatris Gultom, Cyber Law Aspek Hukum Teknologi Informasi (Bandung: Refika Aditama, 2005), hlm. 113.

50 Makarim, supra note 38, hlm. 241. 
menjadikan alat bukti elektronik sebagai alat bukti utama. Dengan adanya alat bukti elektronik dalam KUHAP tidak ada lagi pertentangan pendapat terkait kedudukan alat bukti elektronik sebagaimana kasus kopi sianida Jessica yang memperdebatkan kedudukan barang bukti CCTV sebagai barang bukti utama. Kedua, menjadikannya sebagai alat bukti yang berdiri sendiri memberikan kepastian mengenai kedudukan dan nilai kekuatan pembuktiannya, sehingga menutup celah adanya perbedaan eksistensi alat bukti elektronik dalam undang-undang pidana khusus. Ketiga, lebih mengefektifkan proses pembuktian dan mempercepat hakim untuk memenuhi syarat minimum alat bukti sehingga suatu kasus pidana tidak berjalan berlarut-larut yang berpotensi dihentikan di tengah prosesnya, terutama dalam kasus pidana di dunia maya yang sulit untuk mendapatkan alat bukti fisik. Dengan demikian, eksistensi alat bukti elektronik sebagai alat bukti yang sah dan berdiri sendiri memiliki urgensi untuk segera direalisasikan.

\section{KESIMPULAN}

Berdasarkan ratio legis pembentukan UU Tipikor dan UU PPTPPU yang diperoleh dari proses pembahasan undang-undang tersebut tidak terdapat pembahasan mengenai alasan kedudukan alat bukti elektronik sebagai petunjuk dalam UU Tipikor serta alat bukti elektronik yang berdiri sendiri dalam UU PPTPPU. Pembentuk undang-undang tersebut hanya menjelaskan dua alasan dalam mengakui alat bukti elektronik yaitu sebagai bentuk antisipasi dari perkembangan teknologi dan informasi dan sebagai upaya intensif untuk mengungkap tindak pidana. Dengan alasan yang sama tanpa adanya alasan khusus yang mendasari perbedaan kedudukan alat bukti elektronik tersebut menunjukkan bahwa bentuk pengakuan alat bukti elektronik merupakan kebijakan terbuka (open legal policy) bagi pembentuk undang-undang, sehingga kedudukan alat bukti elektronik dapat diubah dengan mendasarkan pertimbangan yang strategis dalam mempercepat proses pengungkapan tindak pidana.

Perbedaan pengakuan alat bukti elektronik memiliki implikasi hukum yang berbeda. Alat bukti elektronik sebagai perluasan alat bukti petunjuk dalam UU Tipikor memiliki kedudukan yang lebih lemah dari alat bukti lain yakni keterangan saksi, surat, keterangan ahli maupun keterangan terdakwa. Sebagaimana alat bukti petunjuk umumnya, alat bukti elektronik dalam pembuktiannya hanya dapat digunakan dalam keadaan yang sangat mendesak apabila hakim belum mendapat alat bukti minimum atau belum mendapatkan keyakinan atas suatu tindak pidana.

Alat bukti elektronik sebagai perluasan alat bukti petunjuk menjadikan alat bukti elektronik sebagai alat bukti tidak langsung (circumtantial evidence) yang hanya bersifat pelengkap (accesories evidence) dapat digunakan apabila memiliki kesesuaian dengan alat bukti petunjuk lainnya. Di sisi lain, alat bukti elektronik sebagai alat bukti petunjuk membawa konsekuensi bahwa alat bukti ini hanya didasarkan pada penilaian hakim sehingga keputusan untuk menyandarkan putusannya terhadap alat bukti elektronik menjadi otoritas penuh dari hakim tersebut. Sedangkan alat bukti yang 
berdiri sendiri dalam UU PPTPPU bersifat mandiri yang tidak terikat dengan alat bukti lain. Apabila alat bukti elektronik tersebut telah memenuhi syarat materiil dan syarat formil maka alat bukti tersebut dapat langsung digunakan sebagai alat bukti yang sah. Ditinjau dari prinsip minimum pembuktian, alat bukti elektronik yang berdiri sendiri telah memenuhi satu alat yang sah sedangkan alat bukti elektronik sebagai perluasan alat bukti petunjuk masih harus memiliki kesesuaian dan keterkaitan dengan alat bukti lain untuk dapat dijadikan alat bukti yang sah.

Oleh karena itu, perlu untuk memasukkan alat bukti elektronik sebagai alat bukti yang berdiri sendiri dalam KUHAP. Menjadikan alat bukti elektronik sebagai alat bukti yang berdiri sendiri merupakan pilihan yang strategis guna memberikan kedudukan yang kuat terhadap alat bukti elektronik mengingat alat bukti elektronik memiliki peran yang sangat krusial di era digital saat ini.

\section{DAFTAR PUSTAKA}

Al Wisnubroto \& G Widiartana. Pembaharuan Hukum Acara Pidana (Bandung: Citra Aditya Bakti, 2005).

Arief, Barda Nawawi. Tindak Pidana Mayantara (Perkembangan Kebijakan Cyber Crime di Indonesia (Jakarta: RajaGrafindo Perkasa, 2006).

Astuti, Sri Ayu. Perluasan Penggunaan Bukti ELektronik (Evidence of Electronic) terkait Ketentuan Alat Bukti Sah atas Perbuatan Pidana di Ruang Mayantara (Cyberspace) (Paraguyung Law Journal Volume 1 Nomor 1, 2017).

Chazawi, Adami. Hukum Pembuktian Tindak Pidana Korupsi (Bandung: Alumni, 2006).

- - Hukum Pidana Korupsi di Indonesia (Edisi Revisi) (Bandung: Alumni, 2016).

Fuady, Munir. Teori Hukum Pembuktian (Pidana dan Perdata) (Bandung: Citra Aditya Bakti, 2012).

Fikri \& Budiman. Penerapan Asas Lex Specialis Derogat Legi Generalis dan Penyelesaian Sengketa Ekonomi dalam Undang-Undang Perbankan Syariah di Indonesia (Jurnal Al-Ihkam Volume 12 Nomor 1, 2017).

Harahap, M Yahya. Pembahasan Permasalahan dan Penerapan KUHAP Pemeriksaan Sidang Pengadilan, Banding, Kasasi dan Peninjauan Kembali, kedua ed (Jakarta: Sinar Grafika, 2012).

Hiariej, Eddy OS. Teori \& Hukum Pembuktian (Jakarta: Erlangga, 2012).

Isma, Nur Laili \& Arima Koyimatun. Kekuatan Pembuktian Alat Bukti Informasi Elektronik pada Dokumen Elektronik serta Hasil Cetaknya dalam Pembuktian Tindak Pidana (Jurnal Penelitian Hukum Volume 1 Nomor 2, 2014).

Iswanto, Bambang Tjatur \& Nurul Maghfiroh. Alat Bukti dan Masalah yang Timbul dalam Perjanjian sejak Pelaksanaan UU ITE (TRANFORMASI Jurnal Informasi $\&$ Pengembangan IPTEK Volume 11 Nomor 1, 2015).

Makarim, Edmon. Pengantar Hukum Telematika: Suatu Kompilasi (Jakarta: Raja Grafindo Persada, 2005). 
Mansur, Dikdik M Arief \& Elisatris Gultom. Cyber Law Aspek Hukum Teknologi Informasi (Bandung: Refika Aditama, 2005).

Marzuki, Peter Mahmud. Penelitian Hukum Edisi Revisi (Jakarta: Prenadamedia Group, 2015).

Maskun. Kejahatan Siber (Cyber Crime) Suatu Pengantar (Jakarta: Kencana, 2013).

PAF Lamintang \& $\leftarrow$ Theo Lamintang. Pembahasan KUHAP Menurut Ilmu Pengetahuan \& Yurisprudensi (Jakarta: Sinar Grafika, 2013).

Putusan Mahkamah Konstitusi Nomor 20/PUU-XIV/2016 [Putusan Mahkamah Konstitusi Nomor 20/PUU-XIV/2016].

Sasangka, Hari \& Lily Rosita. Komentar Kitab Undang-Undang Hukum Acara Pidana (KUHAP) Buku Pedoman Mahasiswa dan Praktisi (Bandung: Mandar Maju, 2003).

——_. Hukum Pembuktian dalam Perkara Pidana (Bandung: Mandar Maju, 2003).

Sitompul, Josua. Cyberspace, Cybercrimes, Cyberlaw: Tinjauan Aspek Hukum Pidana (Jakarta: Tatanusa, 2012).

Sekretariat Jenderal Dewan Perwakilan Rakyat Republik Indonesia. Naskah Proses Pembahasan Rancangan Undang-Undang Nomor 20 Tahun 2001 tentang Perubahan atas Undang-Undang Nomor 31 Tahun 1999 tentang Pemberantasan Tindak Pidana Korupsi (2001).

- - - Risalah Rancangan Undang-Undang tentang Pencegahan dan Pemberantasan Tindak Pidana Pencucian Uang (2010).

- - - Proses Pembahasan Rancangan Undang-Undang tentang Tindak Pidana Pencucian Uang Buku I.

Suhariyanto, Budi. Tindak Pidana Teknologi Informasi (Cybercrime) Urgensi Pengaturan dan Celah Hukumnya (Depok: Raja Grafindo Persada, 2012).

Suhendi, Hendi. Pentingnya Bukti Elektronik dalam Persidangan Pidana (Jurnal Bina Adhyaksa Volume 7 Nomor 1, 2016).

Tim di bawah Pimpinan Didik Endro Puwoleksono. Naskah Akademik Rancangan Undang-Undang tentang Hukum Acara Pidana (Jakarta: Badan Pembinaan Hukum Nasional Departemen Hukum dan Hak Asasi Manusia RI, 2012).

Undang-Undang Nomor 12 Tahun 2011 tentang Pembentukan Peraturan Perundangundangan (Undang-Undang Nomor 12 Tahun 2011 tentang Pembentukan Peraturan Perundang-undangan).

Undang-Undang Nomor 11 Tahun 2008 tentang Informasi dan Transaksi Elektronik (Undang-Undang Nomor 11 Tahun 2008 tentang Informasi dan Transaksi Elektronik).

"DYAH PENELITIAN HUKUM", online: Issuu 〈https://issuu.com/dosenhukum/docs/dyah_penelitian_hukum〉.

"Kejaksaan Republik Indonesia", online: 〈https://kejaksaan.go.id/unit_kejaksaan.php? idu $=28 \& \& i d s u=35 \& \& i d=4183>$. 